\title{
Effect of Seed-Borne Pathogens against Maize Seedlings In-Vivo Condition
}

\author{
${ }^{1}$ Puspa Devi Bhattarai , ${ }^{2}$ Hari Prasad Aryal \\ Central Department of Botany, Tribhuvan University, Kirtipur, Kathmandu, Nepal
}

\begin{abstract}
Diseases of plants are a major problem for agricultural Worldwide. Fungal diseases have been one of the principal causes of crop loss. Seed-borne diseases are of two types, Internal and external seed-borne pathogens. Seed-borne pathogens results in seed rot, seedlings decay etc. Conditions for treatment of fungus were done in two major ways that is In-vivo and In-vitro way. Field treatment is known as In-vivo treatment. Prevention for the spread of disease is controlled by various techniques, among them Blotter technique was used for the experiment. The objective of the work is to determine the wilting of seedlings then after to compare, its efficacy of seed-borne pathogen of maize. The effects of major seed- borne fungus pathogens against maize seedlings were studied. Experiments were conducted to determine the optimal level of wilting of seedlings separately. The effects of different pathogens were observed on the seedling. Seven days of treatment cause wilting occurs. Major three fungus pathogens (Aspergillus flavus, Aspergillus niger \& Fusarium oxysporum) were sprayed for those experiment separately in separate pots simultaneously. Tested fungus pathogen Aspergillus flavus shows fast witting of seedlings among other two by A. niger and $F$. oxysporum possesses wilting properties respectively. Seed-borne pathogen may be different types of bacteria and can be studied on applying that bacteria in different other plant seedlings rather than maize seedlings.
\end{abstract}

Key-words: Antimicrobial properties, Blotter technique, Nutritive media.

\section{Introduction}

Maize is an important cereal crop in Nepal. In Nepal maize ranks seconds after rice both in area and production. The major and economically important maize diseases reported are gray leaf spot, northern leaf blight, southern leaf blight, bended leaf and sheath blight, ear-rot, stalk-rot, head smut, common rust, downy mildew and brown spot. Maize is the principal staple cereals diet of most of the Nepalese peoples who mainly lives in hilly region. Maize contributed $24.93 \%$ in total edible cereals grains production in Nepal. The total area under maize production is 928.761 ha in Nepal while midhill, terai and high hill occupy $72.85 \%, 17.36 \%$ and $9.79 \%$ respectively(MoAD,2014). The national average yield of maize is $2.46 \mathrm{mt} / \mathrm{ha}$ which is quite low compared to neighboring countries. Maize is the most widely grown crop. Maize is one of the third most important crops in the world. It is the source of nutrition as well as phytochemical compounds. It is mostly produced by small scale farmers. Nepal is an agricultural country and more than $74.8 \%$ of the economically active workers involved in an agriculture (CBS, 2011). The agricultural sector has dominated Nepalese economy for long time and continued to be a major source of livelihood for the majority of population. Agriculture is the main occupation in the rural economy. Maize is also important livestock feed both as silage and as crop residue, grain and is also used industrially for starch and oil extraction. It is an important source of carbohydrates, protein, vitamin B and minerals. Maize is good source of dietary fiber and protein, while being very low in fat and sodium. Maize is one of the important foods, 
${ }^{1}$ Puspa Devi Bhattarai , International Journal of Ayurvedic \& Herbal Medicine 9(2) March.-April. 2018 (3477-3483)

green forest and industrials crop the world. It is called queen of the cereals. Maize has highest yield/ha among the cereals crops. Grain contains protein 10\%, oil 4\%, carbohydrate 70\%, fat $5-75 \%$, and fiber 3-5\%. Pathogen is a type of fungus, bacterium, virus or other microorganisms that can cause disease. Plant disease is a complex phenomenon and is an interaction among the host, parasites and an environment. The crop protection against pathogen, pest and weeds is a major necessity in an agriculture and forestry. A pathogen or a germ in the oldest and broadest sense is anything that can produce disease. Most pathogens are parasites. Seed borne pathogens can infect seed internally and destroy the endosperm and the embryo or contaminate the seed and affect seedling germination and development. Certain seed borne pathogen primarily cause disease of seed and have minor effects on other developmental stages.

Fungal diseases have been one of the principal causes of crop losses ever since humans started to cultivate the plants (Montes-Belmont \& Carvajal, 1998). Major fungal diseases are gray leaf spot, northern leaf blight, southern leaf blight, banded leaf and sheath blight, ear rot, stalk rot, head smut, common rust, downy mildews, brown spot, bacterial diseases are bacterial stalk rot, bacterial leaf strip, stewart wilt and viral diseases are maize mosaic and leaf fleck( Manandhar, 1983). The fungal diseases of plants are primarily controlled by the application of fungicides. It is not an ecofriendly approaches to use synthetic fungicides as many of them are reported to have carcinogenic, teratogenic, oncogenic and genotoxic properties (Dalvi \& whitteker,1995,Hussain et al.,2011). The epidemic spread of fungal disease is controlled by various techniques. Diseases of plants are a major problem for agricultural worldwide. Understanding the mechanism employed by plants to defend themselves against pathogens may lead to novel strategies to enhance the disease resistant in crop plants (Poza et al., 2005). Plants are attached by a number of disease causing organisms (Cardoza, et al., 2002). Biological control and chemical inducers are two promising approaches to the control of plant diseases (Yu \& Zheng, 2006). Biological control of plant pathogens are currently accepted as a major practice in sustainable agriculture because it is based on the management of natural resources. The use of eco-friendly alternative approaches for the management of plant diseases and human diseases are suggested (Mishra \& Tiwari, 1990). Maize (Zea mays L.) is one of the most important cereal grains grown world widely. Fungi are an important group of microorganisms responsible for various diseases of plants and cause yield loss (Kharde et al. 2010). Fungus causes severe reductions in yields and quality. Fungal disease symptoms vary from asymptomatic infection to severe rotting of all plants parts. Fungal infection are the major cause of post-harvest rots of fresh fruits and vegetables during storage, transport and cause significant economic losses in the commercialization phase (Gatto et al.,2011).Frequently observed pathogens , A. niger, A. flavus, F. oxysporum were selected which were also found causing post-harvest loss in maize seed. These microorganisms invade the seeds and cause considerable damage during storage thus rendering it unmarketable and reducing its nutritional and commercial value. Fusarium oxysporum is a fungal pathogen that causes economic losses by inducing necrosis and wilting symptoms in many crop plants. Thus biological control hormonal inducers are two promising approaches to the control of diseases (Samia Khallal, 2007). The movement of the fungus takes place inside the young plant from the roots to the stalk and finally to the cob and kernels (Cornelissen \& Melchers, 1993). More than $25 \%$ of the World cereals are contaminated with known mycotoxins and more than 300 fungal metabolites are reported to be toxic to man and animals (Galvano et al., 2001).

\section{Materials and Methods SAMPLING}

Samples were collected from Koteshwor, Kathmandu and soil from botanical garden of Central Department of Botany, Tribhuvan University was collected and sundried for 21 days and seeds were leave for its germination and analyzed. 
${ }^{1}$ Puspa Devi Bhattarai , International Journal of Ayurvedic \& Herbal Medicine 9(2) March.-April. 2018 (3477-3483) IN VITRO STUDIES MICROORGANISMS

Microorganisms of A. flavus, A. niger and F. oxysporium were cultured from the old maize seed that is these are major seed-borne pathogen. Pure cultures were isolated (Fig1\&2). Pure culture were prepared by culturing and sub-culturing of fungus continuously in constant interval of time and thus obtaining fungus were preserved in slant culture in refrigerator at $4^{\circ} \mathrm{C}(\mathrm{Fig} 3)$.

FUNGAL SUSPENSATION PREPARATION

Pure cultures of each fungus species were isolated and five $\mathrm{ml}$ sterilized water were added to that pure culture containing plate. Fungal suspensions were made with the help of brush. Two $\mathrm{ml}$ of fungal suspension were taken as treatment reagent. Healthy seeds were cultivated on five pots containing sun dry soil i.e., sterilized soil and leave it for its germination at room temperature at about two weeks. Treatment were done after three days of germination and left for few days depending upon the species of fungus which is to be treated.

\section{PDA PREPARATION}

Well sterilized glassware were used, 10 gram of dextrose and 12 gram of agar were added to 100 gram of boiled potato solution. After autoclaved at $121^{\circ} \mathrm{C}$ for 20 minutes at $15 \mathrm{lb}$ pressure, PDA were prepared and used for fungal culture.

\section{PURE CULTURE PREPARATION}

Blotter technique is used for the isolation of fungus. Thus isolated fungus was cultured and sub-cultured time to time to get pure culture of fungus.

\section{IDENTIFICATION}

Seeds of maize were surface sterilized first at tap water and $75 \%$ alcohol for two minutes and glass were also well sterilized. Blotter techniques were used for the growth of fungus. Different kinds of fungus were observed among them major seed-borne fungus were separated by culturing and sub-culturing of this fungus with PDA media until pure culture obtained[Fig.4]. Funguses were identified with the help of different Index Fungorum database and website, microscopic examination, export and related literatures.

\section{IN-VIVO STUDY}

METHODS REGARDING THE FUNGAL SPRAY

After three days of germination of seedlings fungus suspensions were spread with the help of syringes. Two $\mathrm{ml}$ of prepared suspension were taken in syringes and sprayed over seedlings as well as on soil and leave it for few days for proper results. Observations were taken day by day until a week. In this way three different kinds of fungus were sprayed over different pots of seedlings respectively. Five cups for fungus and one cup for control were used for each fungus.

\section{Results}

WILTING OF MAIZE SEEDLINGS

After the spread of fungus suspensions on early seedlings and on soil, the wilting of seedlings occurred. It depends upon the types of fungus (Fig.5,6,7 \&8).

Soil play vital role in germination of plants. Germination depends on the types of soils such as autoclaved soil, field soil and dry soil. Dry soil was mostly preferred in this experiment because it takes less time for maize seed germination i.e., about two weeks. After that autoclaved soil and field soil were preferred for vivo work because it takes three weeks and more than 20 days respectively.

Table 1. Germination of Maize seed in different soils

\begin{tabular}{|l|l|l|}
\hline S.N. & Types of soil & Germination time (days) \\
\hline 1 & Dry soil & Two weeks \\
\hline 2 & Autoclaved soil & Three weeks \\
\hline 3 & Field soil & More than three weeks \\
\hline
\end{tabular}


In this experiment, A. flavus caused early wilting of seedlings i.e., 3-4 days after the treatment. After that $A$. niger shows greater effect towards wilting of seedlings i.e., six days after the treatment. Lastly, $F$. oxysporum shows lower effect towards wilting of seedlings i.e., it takes longer time (7-8 days) for complete wilting.

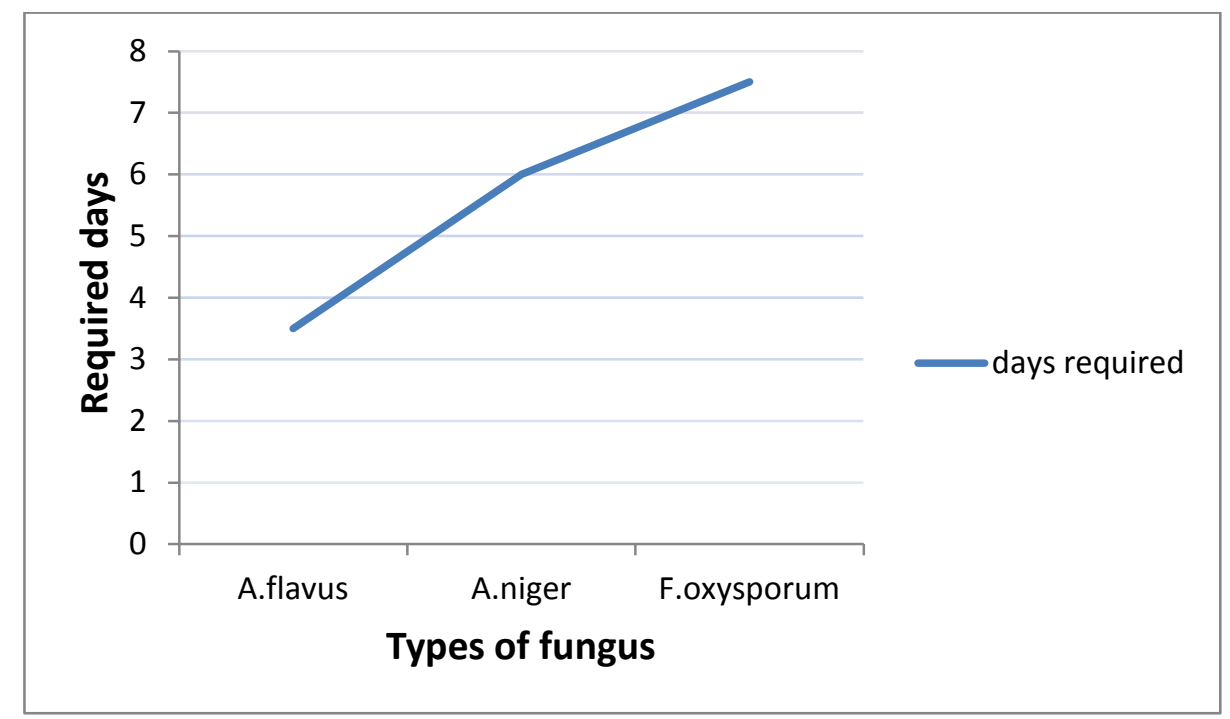

Fig.9. Wilting of seedlings due to different fungus against time.

\section{Discussion}

Plant disease is usually defined as an abnormal growth and /or dysfunction of a plant. Diseases are the result of some disturbance in the normal life process of the plant. Diseases may be the result of living and /or nonliving causes. A variety of chemicals are available that have been designed to control plant diseases by inhibiting the growth or by killing the disease causing pathogens. Bacteria, viruses, insects and adverse conditions create a considerable damaged to the maize seed. A wilt disease is any number of diseases that affect the vascular system of plants. Attacks by fungi, bacteria and nematodes can cause rapid killing of plants, large tree branches or even entire trees. Specific wilt diseases caused by a variety of fungi, bacteria, and viruses. Fungal diseases are often caused by fungi that are common in an environment. Most of the fungus do not caused diseases. However some of them do cause serious diseases. Fungi are responsible for approximately two-third of the infections plant diseases. There are many plant diseases caused by fungi like wilts, mildew, smuts, rust etc. Seed are also susceptible to pathogenic attack due to their nutrient composition. They make them rot and unfit for consumption due to the production of mycotoxins (Stinson et al., 1981, Philips, 1984). Maize is an important crop in temperate climatic region as well as in semi-arid climatic region because of the increasing demands for the food and livestock feed. Successful examples of spray of seedling with $A$. niger, A. flavus and F. oxysporium have been achieved in laboratory and field trials. In fields soil the fungal inoculants didn't stimulate plants growth significantly. Probably, they marginally stimulate growth under ideal conditions where nutrients are more available for plants. The fungus like A. flavus had a much better effect on wilting of seedlings. The untreated (without fungal spray) seedling shows good germination where as treated seedling shows wilting simultaneously. The results obtained from this study suggest that wilting of seedling is due to the cause of fungal spray. Germination of soil depends on soil type as well. Dry soil is mostly preferred for this type of experiment. This study is the first record of early wilting of seedling of maize caused by A. flavus, A. niger and F. oxysporium. In the present investigation the major seed-borne pathogen significantly caused the wilting of seedlings compare with untreated pots, which included the pathogen alone. This was observed for all treatment with each of three funguses with three different soil types. This work was carried out under control green house condition with sterilized soil. 
${ }^{1}$ Puspa Devi Bhattarai , International Journal of Ayurvedic \& Herbal Medicine 9(2) March.-April. 2018 (3477-3483)

Wilting of early stage seedlings is due to the cause of microorganisms. i.e., A. flavus, A. niger and F. oxysporium. These are the major seed-borne pathogens. Hence, It clearly shows that these fungus are major dominate seed-borne pathogens of maize. Other cereals can be treated with numerous fungus as well as bacterial pathogens.

\section{Acknowledgements}

I Acknowledge to Dr. Hari Prasad Aryal for his countineous support during research work. Also a Central Department of Botany, Tribhuvan University for providing the laboratory facilities. Sincere thanks are extended to my family members and Friends.

\section{References}

1. Cardoza, Y. J. Alborn, H.T. \& Tumlinson, J. H. 2002. In-vivo volatile emission from peanut plants induced by simultaneous fungal infection and insect damage. Journal of Chemical Ecology. 28: 161174.

2. CBS 2011, Population Census 2001, National Report. Central Bureau of Statistics

HMG/N Kathmandu.

3. Cornelissen, B.J.C. \& Melchers, L.S. 1993. Strategies for control of fungal diseases with transgenic plants. Journal of Plant Physion. 101: 709-712.

4. Dalvi, R.R. and Whittiker, M.B. 1995.Taxicological implications of the metabolism of benomyl in animals. Journal of Environmental Biology.16: 333-338.

5. Galvano, F. Piva, A. Ritieni, A. \& Galvano, G. 2001.Dietary strategies to counteract the effect of mycotoxins: a review. Journal of Food Protection. 64: 120-131.

6. Gatto, M.A. Ippolito, A. Linsalta, V. Cascarano, N.A. Nigro, F. Vanadia, S. and Di Venere, D. 2011. Activity of extracts from wild edible herbs against post-harvest fungal diseases of fruit and vegetables. Post-harvest Biology and Technology. 61: 72-82.

7. Hussain,H.Badawy,A.Elshazly,A.Elsayed, A. Krohn,K. Riaz,M. and Schulz,B.2011. Chemical constitutes and antimicrobial activity of Salix subserrata. Records of Natural Products. 5: 133.

8. Kharde,M. N.Wabale, A. S. Adhav, R.M.Jadhav, B. D. Wabale, A. M. and Pandey, M. 2010. Effect of plant extracts on fungal pathogens causing leaf blight of tomato in vitro.Asian J. of Exp. Biol. Sci.Spl. 3: 121-123.

9. Manandhar, K.L.1983. Investigation of maize diseases in Nepal-I: Identification and prevalence. Journal of Institute of Agriculture and Animal Science. 4: 45-56.

10. Mishra, M. and Tiwari, S. N. 1990. Ethanolic extract toxicity of three botanicals against five fungal pathogens of rice. National Academy of Science Letters. 13: 409-412.

11. MoAD, 2014, statistical information on Nepalese agriculture 2070/71. Agri-business promotion and statistics division. Ministry of Agriculture Devlopment, Kathmandu, Nepal.

12. Montes-Belmont, R. \& Carvajal, M. 1998. Control of Aspergillus flavus in maize with plant essential oils and their components. Journal of Food Protection. 61: 616-619.

13. Philips, D.J. 1984. Mycotoxins as a post-harvest problem .In: Moline, H.E.(Ed.),Post-harvest Pathology of Fruits and Vegetables. Post-harvest Losses in Peridhable Crops. Agricultural Experimental Stations, University of California. Berkeley Publications. 3: 50-54.

14. Pozo, M.J. \& Aguilar, C. A. 2005. Unraveling micorrhiza induced resistant. Current Opionion in Plant Biology. 10: 393-398.

15. Samia, M. EI-Khallal. 2007. Australian Journal of Basic Applied Science. 1: 691-705. 
${ }^{1}$ Puspa Devi Bhattarai , International Journal of Ayurvedic \& Herbal Medicine 9(2) March.-April. 2018 (3477-3483)

16. Stinson, E.E.Osman,S.F.Heisler,E.G.Siciliano, J. and Bills,D.D. 1981.Mycotoxin production in whole tomatoes , apples,oranges, and lemons. Journal of Agricultural and Food Chemistry. 29: 790792.

17. Yu,T. \& Zheng, X.2006. Salicylic acid enhances by control efficacy of the antagonistic Cryptococcus laurentii in apple fruits. Journal of plant growth regulation. 25: 166-174.

\section{Figures}

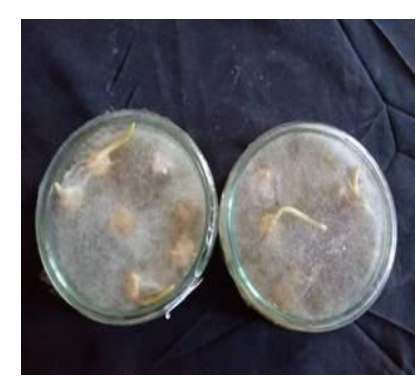

Fig.1. Isolation of fungus from maize seed by Blotter technique

a

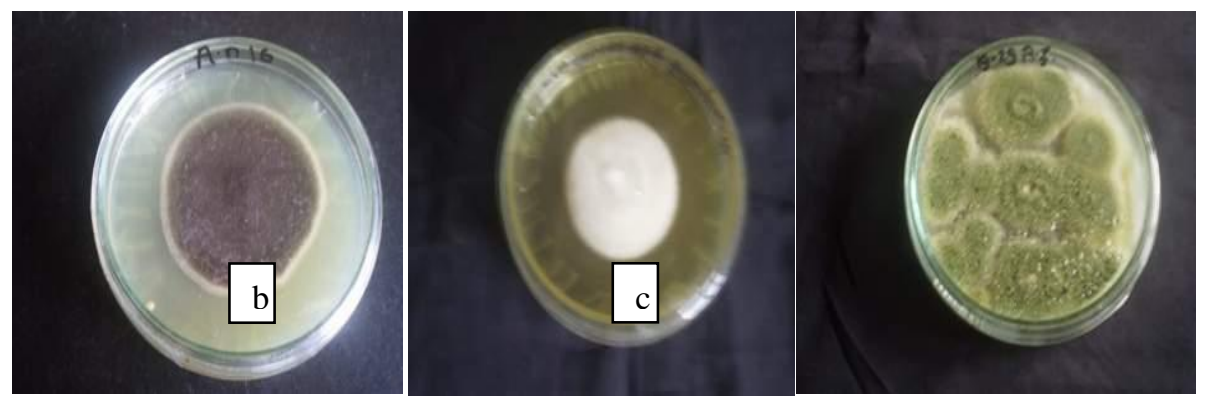

Fig.2. Pure culture of fungi(a) Aspergillus niger (b) Fusarium oxysporum (c) Aspergillus flavus

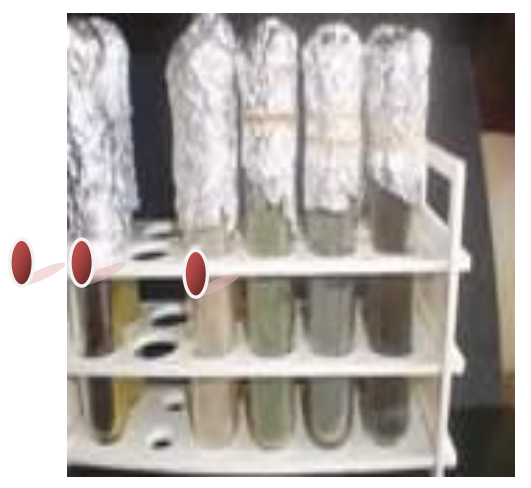

Fig.3. Pure culture of fungus preserved in Agar slant culture
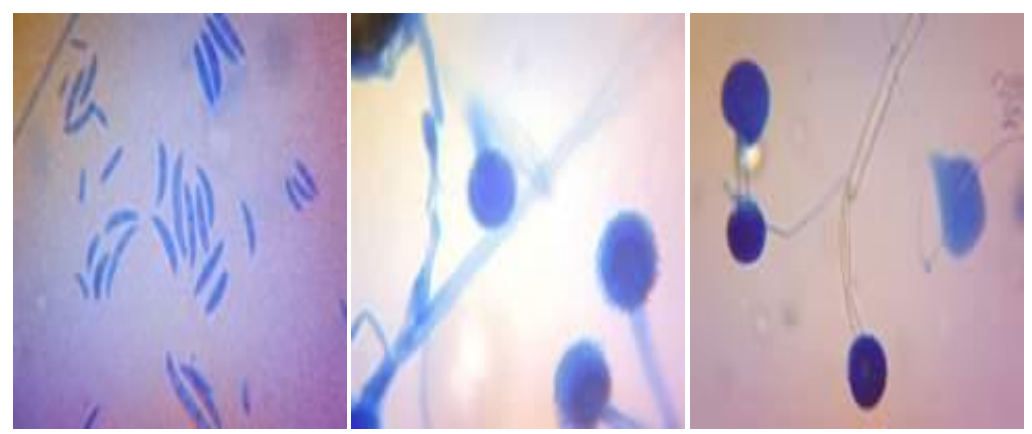

Fig. 4. Microscopic view of F. oxysporium, A. flavus and A. niger (40x) (left to right) 
${ }^{1}$ Puspa Devi Bhattarai , International Journal of Ayurvedic \& Herbal Medicine 9(2) March.-April. 2018 (3477-3483)

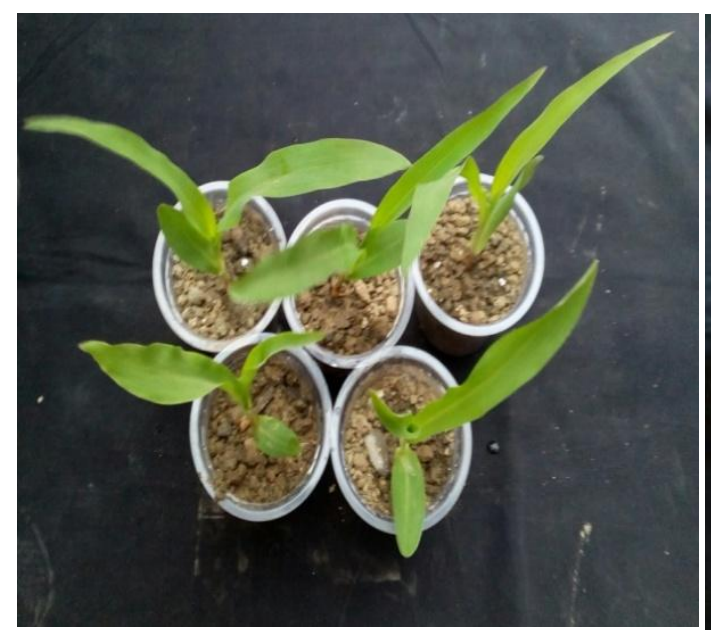

Fig. 5. Germination of Maize seed in control pots

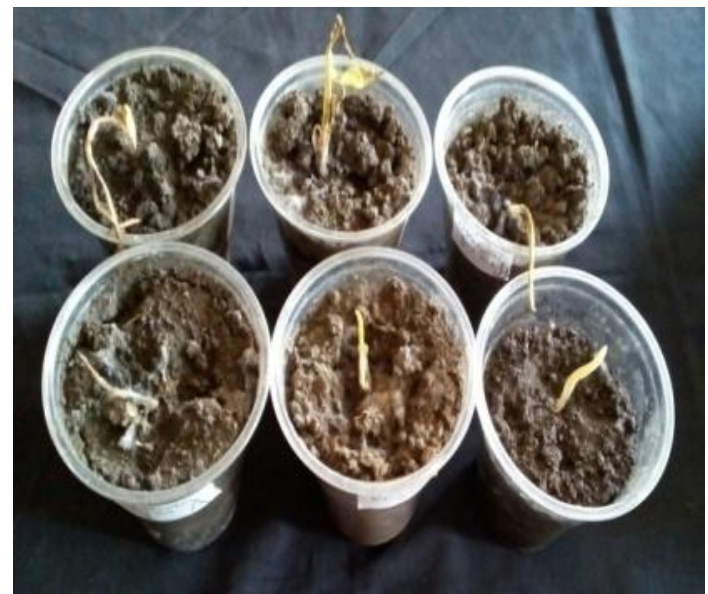

Fig. 7. Wilting due to $F$. oxysporium

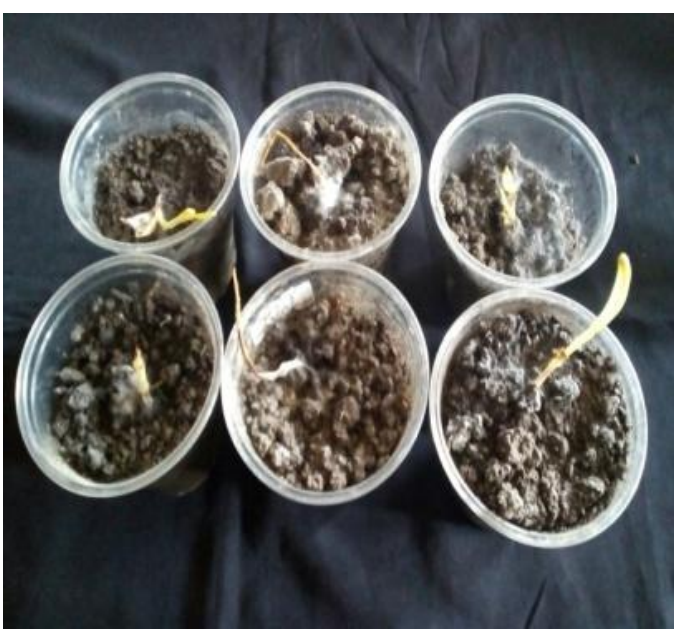

Fig. 6. Wilting due to $A$. niger

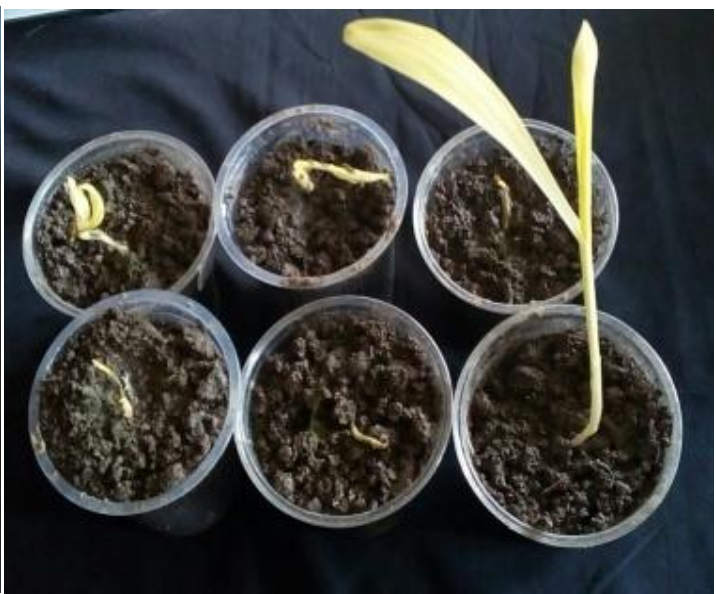

Fig. 8. Wilting due to A. flavus 